\title{
Mycotoxin detoxification of food by lactic acid bacteria
}

\author{
Ahmad Nasrollahzadeh ${ }^{1,2^{*}}$, Samira Mokhtari ${ }^{3}$, Morteza Khomeiri ${ }^{4^{*}}$ (1) and Per Saris ${ }^{3}$
}

\begin{abstract}
Today, a few hundred mycotoxins have been identified and the number is rising. Mycotoxin detoxification of food and feed has been a technically uphill task for the industry. In the twenty-first century, the public demand is healthy food with minimum use of chemicals and preservatives. Among all the fungal inhibition and mycotoxin detoxification methods so far developed for food, biopreservation and biodetoxification have been found safe and reliable. Nowadays, lactic acid bacteria ( $L A B$ ) are of great interest as biological additives in food owing to their Generally Recognized as Safe (GRAS) classification and mycotoxin detoxification capability. The occurrence of fungul growth in the food chain can lead to health problems such as mycotoxicosis and cancer to humans due to producing mycotoxins such as aflatoxins. Biopreservation is among the safest and most reliable methods for inhibition of fungi in food. This review highlights the great potential of $\angle A B$ as biodetoxificant by summarizing various reported detoxification activities of $L A B$ against fungal mycotoxins released into foods. Mechanisms of mycotoxin detoxification, also the inherent and environmental factors affecting detoxifying properties of $L A B$ are also covered.
\end{abstract}

Keywords: Synthetic preservatives, Detoxification yield, Preservation enhancement, Metabolites, Supplementation with $L A B$

\section{Introduction}

Fungi are known as substantial microorganisms in spoilage of food, food products and feed. Spoiling fungi and their toxins contaminate much more than $25 \%$ of raw materials produced by agriculture worldwide (Eskola et al. 2020). Apart from economic loss, the presence of fungi in foodstuff could be along with the production of mycotoxins which are among the components of most concern to human health (Nguegwouo et al. 2018; Leiva et al. 2019). The Rapid Alert System for Food and Feed (RASFF) annual report listed mycotoxins among the 10 top hazards on food products in 2019 (RASFF annual report 2019). Fungal species of, Fusarium, Penicillium and Aspergillus genus which produce fumonisins,

\footnotetext{
*Correspondence: a.nasrollahzadeh@urmia.ac.ir; khomeiri@gau.ac.ir

${ }^{2}$ CEO of Nobonyad Nasr Food Industry Specialists Company, Tehran, Iran

${ }^{4}$ Department of Food Science and Technology, Gorgan University

of Agricultural Sciences and Natural Resources, Gorgan, Iran

Full list of author information is available at the end of the article
}

ochratoxins, trichothecenes, patulins, aflatoxins and zearalenones are considered as main producers of mycotoxins in food products (Magembe et al. 2017; Bhat et al. 2010).

The best strategy is to prevent fungal growth and combat mycotoxins before harvest and during the storage of corps. Mycotoxin contamination however is not ideally controlled at those stages, and alternatives for decontamination, inactivation and removal of mycotoxins in food should be taken to avoid spoilage and infections to humans (Shehata et al. 2019). On the other hand, public also demands minimum chemical preservatives/additives in food; simultaneously, high quality, safe and lease processed food with longest possible shelf life.

Biopreservation is defined as "the use of microorganisms or their metabolites to extend shelf-life and enhance the safety of food commodities" (Stiles 1996). Lactic acid bacteria (LAB) are a group of Gram-positive organisms, some of which have been classified as "Generally Recognized as Safe (GRAS)" by The European Food Safety

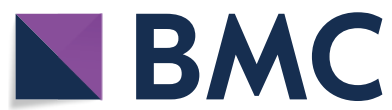

(c) The Author(s) 2021. Open Access This article is licensed under a Creative Commons Attribution 4.0 International License, which permits use, sharing, adaptation, distribution and reproduction in any medium or format, as long as you give appropriate credit to the original author(s) and the source, provide a link to the Creative Commons licence, and indicate if changes were made. The images or other third party material in this article are included in the article's Creative Commons licence, unless indicated otherwise in a credit line to the material. If material is not included in the article's Creative Commons licence and your intended use is not permitted by statutory regulation or exceeds the permitted use, you will need to obtain permission directly from the copyright holder. To view a copy of this licence, visit http://creativecommons.org/licenses/by/4.0/. The Creative Commons Public Domain Dedication waiver (http://creativeco mmons.org/publicdomain/zero/1.0/) applies to the data made available in this article, unless otherwise stated in a credit line to the data. 


\section{Esophagus Brain \\ Fumonisins $\quad$ Aflatoxins, Fumonisins, Trichothecenes}

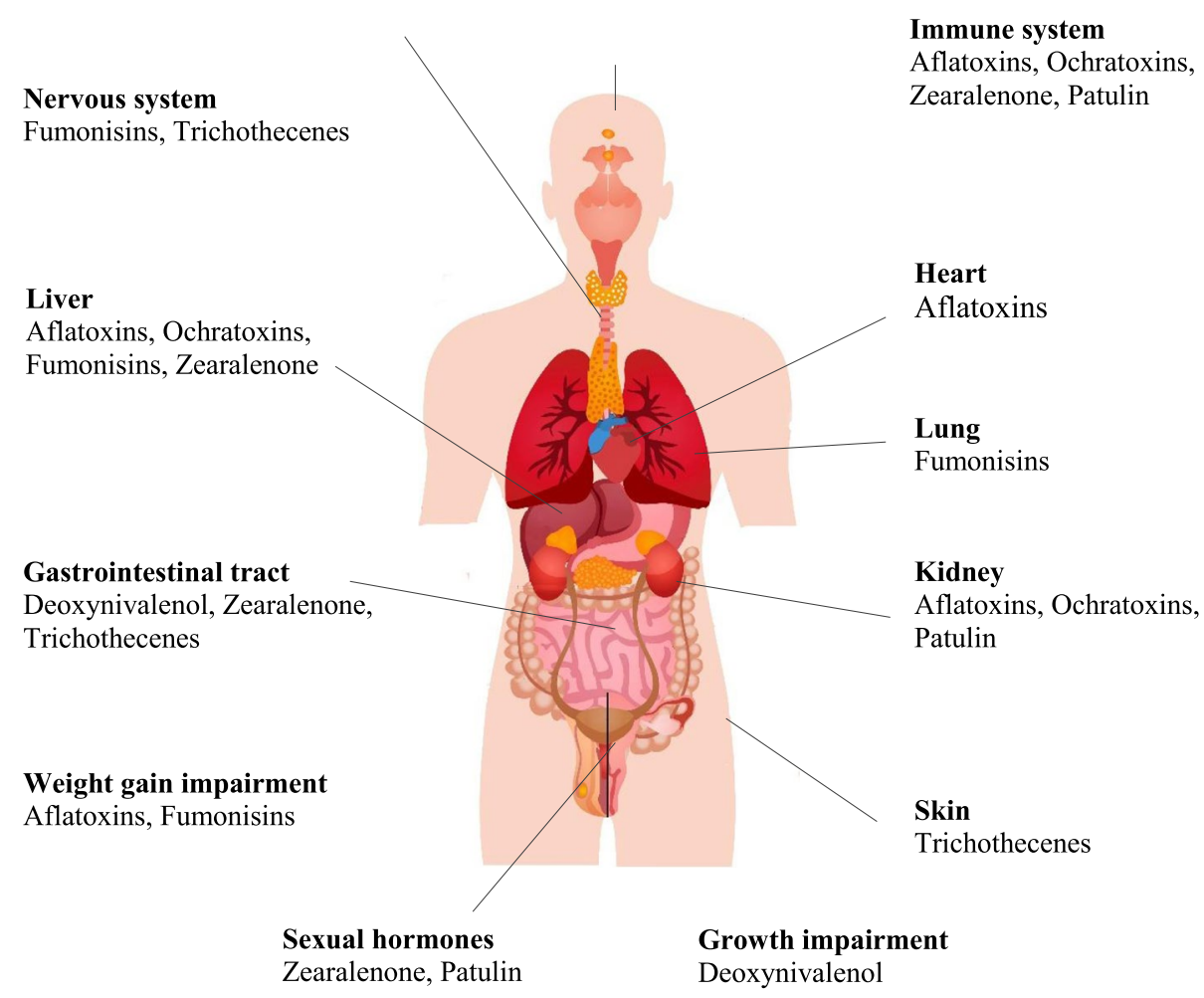

Fig. 1 Harms caused by the most common food-born mycotoxins to human organs. The picture has been designed by Freepik.com

Authority (EFSA) and The Food and Agricultural Organization of the United States (FAO). They are, therefore, qualified to be used as probiotics and biopreservatives in food products (Dalié et al. 2010; Salminen et al. 1998). Studies demonstrated that LAB cultures isolated from native fermented food products with probiotic attributes and mycotoxin binding could be of immense value in decontaminating mycotoxins in food (Drobna et al. 2017; Shetty and Jespersen 2006).

This review summarizes the potential of LAB supplementation as green preservatives in food by highlighting their capability in detoxification of foodborne mycotoxins in vitro and in situ. Different mechanisms of mycotoxin detoxification as well as various characteristics of the food and microorganisms (both fungi and LAB strains) contributing to the detoxification properties of LAB were also overviewed.

\section{Foodborne mycotoxins and their effect on human health}

Mycotoxins are toxic and thermostable secondary metabolites of fungi that can be transferred into food and feed and are able to withstand various food microbial stabilization processes such heating (Oliveira et al. 2014; Conte et al. 2020). Consequently, the contaminated food and feed consumed by humans and animals exposes them to the toxic effects of them (Abdallah et al. 2015). Mycotoxins can grow on many foodstuffs, such as cereals, crops, nuts, fruits and dried fruits, cheese and spices, during all storage, harvesting, and cultivation steps (Patel et al. 2021).

A few hundred mycotoxins mycotoxins have been so far identified, among which, about 30 occur in foods and feeds (Zhang et al. 2016). Aflatoxins, fumonisins, trichothecenes, ochratoxin A and zearalenone are the major foodborne mycotoxins of public health interest (Wu et al. 2014; Nguegwouo et al. 2018). Mycotoxins have been associated with some of mild and chronic human diseases. Their carcinogenic effects on different organs like liver, lung and kidney have been proven. Figure 1 depicts the harms caused by the most common foodborne mycotoxins to human organs.

Mycotoxin contamination is widely reported in food products worldwide, especially in fermented and biologically ripened foods (Chelule et al. 2010a). The main substrates or crops best supporting the growth of fungi 
and release of their mycotoxins are cereals, milk, nuts, oilseeds, dried fruits, coffee and spices, flour and their by-products (Marín et al. 2018; Ofori et al. 2016). Penicillium is the predominant flora in cheese (Sengun et al. 2008). Patulin released by Penicillium expansum was found to pose more potent effects in comparison with other carcinogens such as nitrosamines, polycyclic aromatic hydrocarbons, citrinin and heterocyclic aromatic amines (Knasmüller et al. 2004). Maize and maizebased products are host for Fusarium species who are producer of fumonisins. Fumonisins are thought to be the cause of edema and esophageal cancer in humans (Smith 2018). Ochratoxins are another carcinogen and immunosuppressive mycotoxin happening mostly in cereals produced by Aspergillus and Penicillium species (Blanchard and Manderville 2016). Milk and milk products are another group of food substrate for Aspergillus flavus and Aspergillus parasiticus, the main producers of aflatoxins, one of the most hazardous mycotoxins (Makau et al. 2016). Table 1 illustrates most common food-born mycotoxins, their fungi producer and the main foods host for them.

\section{Mycotoxin detoxification in food systems}

One of the most challenging tasks for the food industry is avoiding/minimizing mycotoxin occurrence and detoxification of mycotoxins in food. Since mycotoxins are mostly heat-stable, cooking and other typical heat processes used in the food industry are not efficient to remove mycotoxins from contaminated food (Chelule et al. 2010b). There are some alternatives for degradation of mycotoxins such as the use of alkaline ammonia as chemical treatment, though not yet favored as they potentially pose side effects to human health and might also alter the properties of the food (Chelule et al. 2010a).

The consequence demand for more natural alternatives for food preservation has driven experts to turn to biological approaches for combating fungal growth and mycotoxin contamination (Guimarães et al. 2018b). Natural preservatives, especially bio-based ones like bacteria and bacteriocins have been extensively studied. Among

Table 1 Most common food-born mycotoxins, their fungi producer and foods host for them

\begin{tabular}{|c|c|c|c|}
\hline Mycotoxin & Food & Fungi & Reference \\
\hline \multirow[t]{5}{*}{ Aflatoxins } & Nuts & \multirow{5}{*}{$\begin{array}{l}\text { A. flavus } \\
\text { A. parasiticus }\end{array}$} & Groopman and Wogan (2015) \\
\hline & Dried fruits & & Lee and Ryu (2015) \\
\hline & Cereals & & Chen et al. (2018) \\
\hline & Milk & & Blanchard and Manderville (2016) \\
\hline & Cheese & & Qian et al. (2014) \\
\hline \multirow[t]{5}{*}{ Ochratoxins } & Cereals & \multirow{5}{*}{$\begin{array}{l}\text { A. ochraceus } \\
\text { A. carbonarius } \\
\text { Penicillium verrucosum }\end{array}$} & Blanchard and Manderville (2016) \\
\hline & Roasted coffee beans Powder & & Shin et al. (2019) \\
\hline & Dried vine Fruits & & \\
\hline & Wine & & \\
\hline & Grape juice & & \\
\hline \multirow[t]{3}{*}{ Fumonisins } & \multirow[t]{3}{*}{ Maize Processed products thereof } & \multirow{3}{*}{$\begin{array}{l}\text { Fusarium verticillioides } \\
\text { F. proliferatum }\end{array}$} & Shephard (2008) \\
\hline & & & Smith (2018) \\
\hline & & & Chen et al. (2018) \\
\hline \multirow[t]{5}{*}{ Deoxynivalenol } & \multirow[t]{5}{*}{ Cereals } & \multirow{5}{*}{$\begin{array}{l}\text { F. sporotrichioides } \\
\text { F.graminearum } \\
\text { F.culmorum } \\
\text { P. poae } \\
\text { F. roseum } \\
\text { F. tricinctum } \\
\text { F. acuminatum }\end{array}$} & Rocha et al. (2014) \\
\hline & & & Wang et al. (2018) \\
\hline & & & Alizadeh et al. (2015) \\
\hline & & & \\
\hline & & & \\
\hline \multirow[t]{2}{*}{ Zearalenone } & \multirow[t]{2}{*}{ Cereals specially corn } & \multirow{2}{*}{$\begin{array}{l}\text { F. granimearum } \\
\text { F.culmorum } \\
\text { F. crookwellense }\end{array}$} & Shephard (2008) \\
\hline & & & Gajęcka et al. (2017) \\
\hline \multirow[t]{4}{*}{ Trichothecenes } & Cereals specially & \multirow[t]{4}{*}{ F. graminearum F. culmorum } & Beasley (2017) \\
\hline & Maize & & Woloshuk and Shim (2013) \\
\hline & Wheat & & \\
\hline & Barley & & \\
\hline \multirow[t]{2}{*}{ Patulin } & \multirow[t]{2}{*}{ Fruits Vegetables Apple juice } & \multirow[t]{2}{*}{ P. expansum } & Speijers et al. (1988) \\
\hline & & & Selmanoglu and Koçkaya (2004) \\
\hline
\end{tabular}


the different potential microorganisms, LAB have been considered as one of the oldest and most promising natural biopreservatives particularly in fermented foods (Shehata et al. 2019; Byakika et al. 2019).

The term "LAB" used for a wide range of Gram-positive, catalase-negative, non-motile and non-spore forming bacteria that produce lactic acid as the main ultimate product of fermentation (Holzapfel and Schillinger 2002). LAB, due to their GRAS status and Qualified Presumption of Safety (QPS) status provided by FDA and EFSA, have greatly appealed researchers to investigate their potential as biopreservatives (Fraqueza 2015; Byakika et al. 2019).

\section{LAB as mycotoxin detoxificant in food}

$L A B$ have been used as mycotoxin detoxifiers in some foods including milk, grains and sorghum beverages for inhibiting aflatoxin M1, Fusarium mycotoxins and aflatoxin, respectively (Haskard et al. 2001; Juodeikiene et al. 2018; Byakika et al. 2019). Stability of mixture in the gastrointestinal tract and resident time are two substantial factors in choosing LAB aimed for mycotoxin in food, though binding strength is highly strain-specific (Shetty and Jespersen 2006).

$\mathrm{LAB}$ could enhance the mycotoxin combat in food via two assistances of being added either in heat treated form or as starter/adjunct cultures to fermented food and beverages; alternatively, by supplementing the food by their purified substances (Juodeikiene et al. 2012). Mainly, there are two mechanisms proposed for LAB mycotoxin detoxification action; physical binding to the cell wall of bacteria, and inhibition of mycotoxin biosynthesis (Dalié et al. 2010). Number of studies reporting the detoxification attribute of LAB species against mycotoxins are listed in Table 2.

\section{Reduction of mycotoxin biosynthesis and degradation of mycotoxins}

$\mathrm{LAB}$ were found to contribute to reducing the biosynthesis of mycotoxin by fungi. Cell-free supernatant of $L b$. plantarum UM55 and Lb. buchneri UTAD104 reduced the production of ochratoxin from $P$. nordicum by $60 \%$. Phenyllactic (PLA), acetic acid and indole lactic (ILA) were found to be the most effective substances causing the effect (Guimarães et al. 2018a). In another study from the same group, it was shown that cell-free supernatant of $L b$. plantarum UM55 inhibits the production of aflatoxins from $A$. flavus by $91 \%$. They attributed the antiaflatoxigenic properties of LAB to the strain's capability to produce lactic acid, PLA, OH-PLA and ILA. In their study, PLA exhibited a stronger activity, also 90\% inhibitory concentration (IC90) for the aflatoxins was

Table 2 Detoxification extent of food mycotoxins by LAB

\begin{tabular}{|c|c|c|c|}
\hline LAB & Mycotoxin & Detoxification \% & Reference \\
\hline$L b$. plantarum and $L b$. fermentum & Aflatoxin B1 & 60 & Shetty and Jespersen (2006) \\
\hline$L b$. fermentum, Lb. easel and $L b$. plantarum & Aflatoxin B1 & $25-61$ & Fazeli et al. (2009) \\
\hline Enterococcus faecium M74 and EF031 & Aflatoxin B1 & $19.3-37.5$ & Topcu et al. (2010) \\
\hline $\begin{array}{l}\text { Lb. acidophilus, Lb. brevis, Lb. casei, Lb. delbruekii, and Lb. } \\
\text { plantarum }\end{array}$ & Aflatoxin B1 & 29.9 & Oluwafemi et al. (2010) \\
\hline LAB flora of amahewu & $\begin{array}{l}\text { Aflatoxin B1 Fumonisins } \\
\text { B1 Zearalenone }\end{array}$ & $\begin{array}{l}93 \\
88 \\
84\end{array}$ & Chelule et al. (2010a) \\
\hline LAB and S. cerevisiae & $\begin{array}{l}\text { Aflatoxin } \\
\text { Ochratoxin A }\end{array}$ & $\begin{array}{l}15 \\
20\end{array}$ & Biernasiak et al. (2006) \\
\hline Lb. sakei, P.acidilactici, and Pediococcus pentosaceus & $\begin{array}{l}\text { Zearalenone, Deoxyniva- } \\
\text { lenol, T-2 } \\
\text { HT-2 }\end{array}$ & $\begin{array}{l}23 \\
34 \\
58 \\
73\end{array}$ & Juodeikiene et al. (2018) \\
\hline Lb. acidophilus & Aflatoxin B1 & 80 & Marrez et al. (2018) \\
\hline Lacticaseibacillus and Bifidobacterium & Ochratoxin A & $30-99$ & Luz et al. (2017) \\
\hline Lb. plantarum UM55 CFS & $\begin{array}{l}\text { Aflatoxin B1 } \\
\text { Aflatoxin B2 } \\
\text { Aflatoxin G1 } \\
\text { Aflatoxin G2 }\end{array}$ & $16-97$ & Guimarães et al. (2018b) \\
\hline Lb. plantarum UM55 and Lb. buchneri UTAD104 & Ochratoxin A & 60 & Guimarães et al. (2018a) \\
\hline Bifidobacterium Lb. fermentum & $\begin{array}{l}\text { Aflatoxin B1 } \\
\text { Aflatoxin B2 } \\
\text { Aflatoxin G1 } \\
\text { Aflatoxin G2 }\end{array}$ & $88.8-99.8$ & Ghazvini et al. (2016) \\
\hline
\end{tabular}


obtained $0.87 \mathrm{mg} / \mathrm{ml}$. Aflatoxins IC90 for ILA, OH-PLA and lactic acid were of $1.47,1.80$, and $3.92 \mathrm{mg} / \mathrm{ml}$, respectively (Guimarães et al. 2018b).

Concentration of supernatant was found influential in mycotoxin biosynthesis reduction of LAB. According to Shehata et al. (2019) cell free supernatant of Lactobacillus sp. RM1 at the concentration of $5 \mathrm{mg} / \mathrm{ml}$, reduced the aflatoxin production of $A$. parasiticus ITEM 11 and $A$. flavus ITEM 698 whereas it stopped aflatoxin production of the strains at 15 and $10 \mathrm{mg} / \mathrm{ml}$ concentration. Similarly, the production of ochratoxin A by $A$. carbonarius ITEM 5010 reduced about 5-folds at a concentration supernatant of $10 \mathrm{mg} / \mathrm{ml}$ and stopped at the concentration of $15 \mathrm{mg} / \mathrm{ml}$ (Shehata et al. 2019). There are some mechanisms proposed for the reduction of mycotoxin biosynthesis by LAB. The first possibility is the release of molecules due to the natural lysis of LAB which inhibit fungal growth; as a result, lowering their mycotoxin production (Dalié et al. 2010). Later, it was also suggested that bioactive compounds secreted by LAB such as organic acids, PLA, reuterin, fatty acids, peptides and cyclic peptides are capable to interact with mycotoxins; consequently, reduce their amount in food (Muhialdin et al. 2020).

The capability of the main acids produced from $L A B$ in the degradation of aflatoxin B1 was compared in a study. They heated aflatoxin $\mathrm{B} 1$ at $80^{\circ} \mathrm{C}$ in the presence of lactic, acetic and citric acids for different times. Lactic acid was most efficient among all three in degrading aflatoxin B1 to less toxic aflatoxin B2a or aflatoxin B2 (Aiko et al. 2016). In another study, a cyclic dipeptide detected from $P$. pentosaceus supernatant was detected as the main substance responsible for anti-aflatoxigenic effect of the strain binding aflatoxin from $A$. niger (Ebrahimi et al. 2020). Juodeikiene et al. (2018), observed that treatment of malting grains with $L b$. sakei KTU05-6, P. pentosaceus KTU05-8, P. acidilactici KTU05-7 and KTU05-09, and KTU05-10 strains reduced level of zearalenone, deoxynivalenol, T-2 and HT-2 toxin concentrations by $23,34,58$ and $73 \%$, respectively. They reported that the reduction was probably due to either physical binding or degradation of mycotoxins (Juodeikiene et al. 2018).

\section{Mycotoxin binding}

Since LAB bind mycotoxins in both dead and alive forms, the mechanism of mycotoxin removal in many reports was explained to be through the cell wall of LAB binding the toxins. Reduction of aflatoxin M1 in three different contaminated samples of phosphate buffer saline, skim and full cream milk was found independent of the viability of LAB cells. No significant difference between the binding ability of viable and heat-killed cells supports the mycotoxin removal activity of LAB through physical mechanism rather than the metabolic or covalent function of the cells (Pierides et al. 2000). Later also, heatkilled LAB cells removed aflatoxin $M_{1}$ more efficiently than viable cells in both contact times of $15 \mathrm{~min}$ and $24 \mathrm{~h}$. The difference was explained because treatment exposes the binding spots of the cell walls which facilitates binding (Bovo et al. 2013). Heat and acid treatments affect the cell wall binding sites through two major constructive compounds of polysaccharides and proteins. The treatments denature proteins and degrade them to smaller peptides by breakage of protein ammonium sulfate bonds, they also break down polysaccharide glycosidic bond loosening peptidoglycan monosaccharide which leads to exposing more binding sites (Lili et al. 2018). Supporting this fact is the study of Haskard et al. (2001) where they observed that several times of washing with water left 38 and $50 \%$ of the bound toxins to the viable cells of Lb. rhamnosus strains LGG and LC105 retained, respectively. This was while heat and acid treated cells retained higher percentage of the toxin by $66-71 \%$ (Haskard et al. 2001). Another example is reduction of deoxynivalenol (DON) was reported through physical binding by Lactobacillus strains and the cell wall of the yeast Saccharomyces cerevisiae (Ghamsari et al. 2021). Moreover, DON was removed in liquid culture by $40.7 \%$ through cell wall binding with Lactobacillus paracasei LHZ-1 (Zhai et al. 2019).

Removal of mycotoxins was demonstrated to reduce the ability of the LAB strain to adhere which provides evidence for the cell wall binding mycotoxin detoxification mechanism of LAB. Kankaanpää et al. (2000) believe that employing $\mathrm{LAB}$ could reduce aflatoxins in the intestine since they observed that after Lb. rhamnosus GG being subjected to aflatoxin B1 experiment lost its adhesion ability from $30 \%$ to $5 \%$ indicating that aflatoxins may influence the adhesion properties of probiotics (Kankaanpää et al. 2000). Similarly, Gratz et al. (2004) observed that binding of Lb. rhamnosus GG to intestinal mucus reduced after pre-treatment of bacterial cells with aflatoxin $\mathrm{B} 1$, though the pre-incubation of the cells with intestinal mucus also its ability to bind aflatoxin B1. Mycotoxin binding by LAB was reported to be a rapid reaction and dependent on the bacterial density. Lb. rhamnosus LGG and LC 705 were shown to bind zearalenone and its derivative up to $55 \%(\mathrm{w} / \mathrm{w}$, Gratz et al. 2004). This was while co-incubation of zearalenone and its derivative reduced the quantity of the toxins bound which indicates that the binding sites on the cell wall were shared between the toxins, thus less density of cells available for each one (El-Nezami et al. 2002b).

LAB cell wall, as Gram positive bacteria, consists of peptidoglycan network embedding teichoic acid, lipoteichoic acid and S-layer as other main substances 
present in the cell wall (Delcour et al. 1999). The binding function of the cell wall is directed by these major components, alone or in cooperation (Haskard et al. 2001). Studying the mechanism of aflatoxin cell wall binding to $L b$. rhamnosus using enzyme treatments demonstrated that the binding occurred through carbohydrate and protein content of the cell wall. The same study highlighted the contribution of hydrophobic interactions in binding since treatment with urea in their experiments decreased the binding (Haskard et al. 2000). Lahtinen et al. (2004), however, emphasized the greater role of carbohydrates of peptidoglycan or the structures closely associated with peptidoglycan in the Aflatoxin B1 binding process (Lahtinen et al. 2004).

Mycotoxin binding properties of LAB are highly strain-specific. Many studies have demonstrated that $\mathrm{LAB}$ strains bind mycotoxins with different strengths. Lb. rhamnosus LGG and LC 705 and Propionibacterium freudenreichii were shown to effectively bind some of common Fusarium toxins such as deoxynivalenol, nivalenol, 3-acetyldeoxynivalenol, diacetoxyscirpenol, fusarenon, T-2 toxin and HT-2 toxin. The strains bound the toxins in different levels, $L b$. rhamnosus strains LGG and LC 705 presenting higher binding ability towards aflatoxin B1 than aflatoxin B2 and G1 (El-Nezami et al. 2002a). Shetty and Jespersen (2006) also reported the same fact where 15 strains of LAB were tested, and $L b$. plantarum and $L b$. fermentum among others were found to bind higher than $60 \%(\mathrm{w} / \mathrm{w})$ of aflatoxin B1 (Shetty and Jespersen 2006). In another study, Drobna et al. (2017), reported that 5 LAB strains bound $10.8-66.7 \%$ of aflatoxin $\mathrm{B} 1$ present in the samples in vitro. The best results concerning aflatoxin $\mathrm{B} 1$ reduction and reproducibility of the reduction process were from $L b$. reuteri $\mathrm{KO} 4 \mathrm{~b}$ strain $(66.7 \% \pm 1.0 \%)$ followed by $L b$. plantarum KG4 $(59.4 \% \pm 1.6 \%)$ after an incubation of $24 \mathrm{~h}$ (Drobna et al. 2017).

\section{Factors affecting mycotoxin binding activity of $L A B$}

The effectiveness of LAB strains in binding mycotoxins is determined by multiple factors like cell density, concentration of toxins, $\mathrm{pH}$ value, viability and temperature. Haskard et al. (2001) investigated the binding ability of aflatoxin B1 by three forms of viable, heat-killed and acid-killed $L b$. rhamnosus strain GG. They reported that there was no significant difference between all three forms of cells in terms of binding ability. Since treatment with periodate, resulted in the highest aflatoxin B1 binding, they concluded that binding occurs predominantly through carbohydrates of bacterial cells. Urea also caused a reduction in aflatoxin B1 binding for all bacteria, suggesting that hydrophobic interactions also largely contributes to binding. Finally, increasing $\mathrm{NaCl}$ or $\mathrm{CaCl}_{2}$ concentrations did not significantly affect aflatoxin $B_{1}$ binding which implies mediation of electrostatic interactions (Haskard et al. 2001). Hydrogen bonding interactions were found to play role in binding ability of LAB as an increase in $\mathrm{pH}$ from 2.5 to 8.5 did not influence the aflatoxin B1 binding ability of Lactobacillus GG while decreased binding of aflatoxin B2a (Haskard et al. 2000).

The impact of temperature in detoxification of mycotoxins was highlighted by Bovo et al. (2013) where they reported that LAB strains of Lb. bulgaricus, Lb. rhamnosus and Bifidobacterium lactis bound aflatoxin $\mathrm{M}_{1}$ in values of 13,19 and $37 \%$ at $4{ }^{\circ} \mathrm{C}$ and 33,24 and $32 \%$ at $37^{\circ} \mathrm{C}$, respectively. In another study, Shehata et al. (2019) increasing temperature from 28 to $37^{\circ} \mathrm{C}$ caused a significant decrease in antifungal activity of Lactobacillus sp. RM1 against $A$. parasiticus (Bovo et al. 2013).

Incubation time also was found effective in the detoxification ability of LAB. Drobna et al. (2017) tested the ability of $5 \mathrm{LAB}$ strains to bind $\mathrm{AB} 1$ in vitro. According to their results, the extent of binding ability was directly proportional to the length of incubation with aflatoxin B1 for all strains except $L b$. mucosae D strain, which showed a decreased activity with time. They observed that aflatoxin $\mathrm{B} 1$ reduction and reproducibility of the reduction process were obtained with $L b$. reuteri $\mathrm{KO} 4 \mathrm{~b}$ strain $(66.7 \% \pm 1.0 \%)$ followed by $L b$. plantarum KG4 $(59.4 \% \pm 1.6 \%)$ after an incubation of $24 \mathrm{~h}$ (Drobna et al. 2017).

The role of $\mathrm{pH}$ in the binding ability of LAB also was revealed in another study. Guimarães et al. (2018b) reported that inhibition of $L b$. plantarum UM55 against A. flavus was dependent on the $\mathrm{pH}$ of cell-free supernatant, increased with increasing concentrations of cellfree supernatant. Increasing the $\mathrm{pH}$ from 5 to $7 \mathrm{did}$ not significantly affect the antifungal properties of Lacticaseibacillus sp. RM1 against A. parasiticus, A. flavus and A. carbonarius (Shehata et al. 2019). Raisin pH above 7, however, resulted in a drop of activity by $50 \%$ (Guimarães et al. 2018b).

\section{Conclusion and future perspectives}

Fungal spoilage of food is implicated in many food poisoning outbreaks in human and animals by producing mycotoxins with possible carcinogenic and teratogenic effects. Application of LAB species with mycotoxin detoxification properties in food was reported to reduce mycotoxins. Mycotoxin detoxification by LAB is mainly based on adhesion of mycotoxins to the cell wall peptidoglycan structure of $\mathrm{LAB}$, also reducing mycotoxin synthesis and degradation of mycotoxins. Additionally, mycotoxin detoxification properties of LAB is strainspecific meaning that different $L A B$ strains might or might not bind a particular mycotoxin, and binding 
strength varies from strain to strain. Binding activity and strength depends on $\mathrm{pH}$ of food, storage temperature, $\mathrm{LAB}$ cell density and concentration of mycotoxins in food. Therefore, multiple factors including the properties of the food itself and the potential mycotoxins and their fungi producer as well as LAB strains should be taken to account before employing LAB as mycotoxin detoxification agents in food.

Valuable advances in detection of LAB strains with antifungal activities and their active substances have been achieved in recent years. There is still, however, a need for further investigation to be pursued in the biochemical basis of the detoxification mechanism of LAB. A better understanding of detoxification LAB biochemical pathways will provide insights into the production of potential mycotoxin detoxifying bioactive compounds. Regarding that studies in this area are mostly lab-scale reports, a promising strategy at this stage might be directing studies more in line with industrializing these findings. The pathways and mechanism of action of LAB as detoxificant could be also investigated for targeted food poisoning therapy by clinicians associated with toxicology.

\section{Abbreviations \\ LAB: Lactic Acid Bacteria; GRAS: Generally Recognized as Safe; RASFF: The Rapid Alert System for Food and Feed; EFSA: The European Food Safety Authority; FAO: The Food and Agricultural Organization of the United States; QPS: Qualified Presumption of Safety.}

\section{Acknowledgements}

The authors would like to acknowledge Magnus Foundation and Niemi Foundations for supporting this publication.

\section{Authors' contributions}

All the authors contributing to this work are listed in names. The authors have contributed to writing the manuscript as the order of their names. The author(s) read and approved the final manuscript.

\section{Funding}

This work was supported by the Magnus Foundation under grant number 10-8352-12 and Niemi Foundation under grant number 20190109.

\section{Availability of data and materials}

Not applicable.

\section{Declaration}

\section{Competing interests}

There is no competing interests.

\begin{abstract}
Author details
${ }^{1}$ Department of Food Science and Technology, Urmia University, Urmia, Iran. ${ }^{2}$ CEO of Nobonyad Nasr Food Industry Specialists Company, Tehran, Iran. ${ }^{3}$ Department of Microbiology, Faculty of Agriculture and Forestry, University of Helsinki, Helsinki, Finland. ${ }^{4}$ Department of Food Science and Technology, Gorgan University of Agricultural Sciences and Natural Resources, Gorgan, Iran.
\end{abstract}

Received: 25 April 2021 Accepted: 28 October 2021

Published online: 07 January 2022

\section{References}

Abdallah MF, Girgin GÖZDE, BaydarT (2015) Occurrence, prevention and limitation of mycotoxins in feeds. Anim Nutr Feed Technol 3:471-490. https:// doi.org/10.5958/0974-181X.2015.00048.7

Aiko V, Edamana P, Mehta M (2016) Decomposition and detoxification of aflatoxin B1 by lactic acid. J Sci Food Agric 96:1959-1966. https://doi.org/ 10.1002/jsfa.7304

Alizadeh A, Braber S, Akbari P, Garssen J, Fink-Gremmels J (2015) Deoxynivalenol impairs weight gain and affects markers of gut health after low-dose, short-term exposure of growing pigs. Toxins 76:2071-2095. https://doi. org/10.3390/toxins7062071

Beasley VR (2017) Trichothecene Mycotoxicosis pathophysiologic effects (1989). CRC Press, United States. https://doi.org/10.1201/9781315121260

Bhat R, Rai RV, Karim AA (2010) Mycotoxins in food and feed: present status and future concerns. Compr Rev Food Sci F 9:57-81. https://doi.org/10. 1111/j.1541-4337.2009.00094.x

Biernasiak J, Piotrowska M, Libudzisz Z (2006) Detoxification of mycotoxins by probiotic preparation for broiler chickens. Mycotoxin Res 22:230-235. https://doi.org/10.1007/BF02946747

Blanchard DJ, Manderville RA (2016) An internal charge transfer-DNA platform for fluorescence sensing of divalent metal ions. ChemComm 52:95869588. https://doi.org/10.1039/C6CC04613D

Bovo F, Corassin CH, Rosim RE, de Oliveira CA (2013) Efficiency of lactic acid bacteria strains for decontamination of aflatoxin $\mathrm{M} 1$ in phosphate buffer saline solution and in skimmed milk. Food Bioprocess Technol 68:2230-2234. https://doi.org/10.1007/s11947-011-0770-9

Byakika S, Mukisa IM, Wacoo AP, Kort R, Byaruhanga YB, Muyanja C (2019) Potential application of lactic acid starters in the reduction of aflatoxin contamination in fermented sorghum-millet beverages. Int J Food Contam 6:4. https://doi.org/10.1186/s40550-019-0074-9

Chelule P, Mbongwa H, Carries S, Gqaleni N (2010a) Lactic acid fermentation improves the quality of amahewu, a traditional south African maizebased porridge. Food Chem 122:656-661. https://doi.org/10.1016/j.foodc hem.2010.03.026

Chelule P, Mokoena M, Gqaleni N (2010b) Advantages of traditional lactic acid bacteria fermentation of food in Africa. Current research, technology and education topics in Appl. Microbiol. Biotechnol 2:1160-1167

Chen C, Mitchell NJ, Gratz J, Houpt ER, Gong Y, Egner PA et al (2018) Exposure to aflatoxin and fumonisin in children at risk for growth impairment in rural Tanzania. Environ Int 115:29-37. https://doi.org/10.1016/j.envint. 2018.03.001

Conte G, Fontanelli M, Galli F, Cotrozzi L, Pagni L, Pellegrini E (2020) Mycotoxins in feed and food and the role of ozone in their detoxification and degradation: an update. Toxins 8:486. https://doi.org/10.3390/toxins12080486

Dalié D, Deschamps A, Richard-Forget F (2010) Lactic acid bacteria-potential for control of mould growth and mycotoxins: a review. Food Control 21:370-380. https://doi.org/10.1016/j.foodcont.2009.07.011

Delcour J, Ferain T, Deghorain M, Palumbo E, Hols P (1999) The biosynthesis and functionality of the cell-wall of lactic acid bacteria. Lactic Acid Bacteria 76:159-184. https://doi.org/10.1007/978-94-0172027-4_7

Drobna E, Rauova D, Majekova H, Greif G, Mikus P (2017) Antifungal activity and aflatoxin binding ability of Lactobacillus species isolated from lamb and goatling stomach mucus. J Food Nutr Res 56:255-264. https://doi. org/10.2174/1874285801610010197

Ebrahimi M, Sadeghi A, Mortazavi SA (2020) The use of cyclic dipeptide producing $L A B$ with potent anti-aflatoxigenic capability to improve technofunctional properties of clean-label bread. Ann Microbiol 70:1-12. https:// doi.org/10.1186/s13213-020-01571-y

El-Nezami H, Chrevatidis A, Auriola S, Salminen S, Mykkänen H (2002a) Removal of common Fusarium toxins in vitro by strains of Lactobacillus and Propionibacterium. Food Addit Contam 19:680-686. https://doi.org/ 10.1080/02652030210134236

El-Nezami H, Polychronaki N, Salminen S, Mykkänen H (2002b) Binding rather than metabolism may explain the interaction of two food-grade lactobacillus strains with zearalenone and its derivative á-zearalenol. Appl Environ Microbiol 68:3545-3549. https://doi.org/10.1128/AEM.68.7. 3545-3549.2002

Eskola M, Kos G, Elliott CT, Hajšlová J, Mayar S, Krska R (2020) Worldwide contamination of food-crops with mycotoxins: Validity of the widely cited 'FAO estimate' of 25\%. Crit Rev Food Sci Nutr 60(16):2773-2789 doi.org/ 10.1080/10408398.2019.1658570 
Fazeli MR, Hajimohammadali H, Moshkani A, Samadi N, Jamalifar H, Khoshayand MR, Vaghari E, Pouragahi S (2009) Aflatoxin B1 binding capacity of autochthonous strains of lactic acid bacteria. J Food Prot 72:189-192. https://doi.org/10.4315/0362-028x-72.1.189

Fraqueza MJ (2015) Antibiotic resistance of lactic acid bacteria isolated from dry-fermented sausages. Int J Food Microbiol 212:76-88. https://doi.org/ 10.1016/j.ijfoodmicro.2015.04.035

Gajęcka M, Zielonka Ł, Gajęcki M (2017) Activity of zearalenone in the porcine intestinal tract. Molecules 22:18. https://doi.org/10.3390/molecules2 2010018

Ghamsari FA, Ebrahimi MT, Varzaneh MB, Iranbakhsh A, Sepahi AA (2021) In vitro reduction of mycotoxin deoxynivalenol by organic adsorbent. J Food Process Preserv 3:e15212 doi.org/10.1111/jfpp.15212

Ghazvini RD, Kouhsari E, Zibafar E, Hashemi SJ, Amini A, Niknejad F (2016) Antifungal activity and aflatoxin degradation of Bifidobacterium bifidum and Lactobacillus fermentum against toxigenic Aspergillus parasiticus. Open Microbiol J 10:197-201. https://doi.org/10.2174/1874285801610010197

Gratz S, Mykkänen H, Ouwehand A, Juvonen R, Salminen S, El-Nezami H (2004) Intestinal mucus alters the ability of probiotic bacteria to bind aflatoxin B1 in vitro. Appl Environ Microbiol 70:6306-6308. https://doi.org/10.1128/ AEM.70.10.6306-6308.2004

Groopman JD, Wogan G (2015) Encyclopedia of food and health. Academic Press. https://doi.org/10.1016/B978-0-12-384947-2.00015-5

Guimarães A, Santiago A, Teixeira JA, Venâncio A, Abrunhosa L (2018b) Anti-aflatoxigenic effect of organic acids produced by Lactobacillus plantarum. Int J Food Microbiol 264:31-38. https://doi.org/10.1016/j.ijfoo dmicro.2017.10.025

Guimarães A, Venancio A, Abrunhosa L (2018a) Antifungal effect of organic acids from lactic acid bacteria on Penicillium nordicum. Food Addit Contam 359:1803-1818. https://doi.org/10.1080/19440049.2018.1500718

Haskard C, Binnion C, Ahokas J (2000) Factors affecting the sequestration of aflatoxin by Lactobacillus rhamnosus strain GG. Chem Biol Interact 128:39-49. https://doi.org/10.1016/s0009-2797(00)00186-1

Haskard CA, El-Nezami HS, Kankaanpää PE, Salminen S, Ahokas JT (2001) Surface binding of aflatoxin B1 by lactic acid bacteria. Appl Environ Microbiol 67:3086-3091. https://doi.org/10.1128/AEM.67.7.3086-3091.2001

Holzapfel WH, Schillinger U (2002) Introduction to pre-and probiotics. Food Res Int 352:109-116. https://doi.org/10.1016/S0963-99690100171-5

Juodeikiene G, Bartkiene E, Cernauskas D, Cizeikiene D, Zadeike D, Lele V, Bartkevics V (2018) Antifungal activity of lactic acid bacteria and their application for Fusarium mycotoxin reduction in malting wheat grains. LWT 89:307-314. https://doi.org/10.1016/j.lwt.2017.10.061

Juodeikiene G, Basinskiene L, Bartkiene E, Matusevicius P (2012) Mycotoxin decontamination aspects in food, feed and renewables using fermentation processes. J Food Eng 171-204. https://doi.org/10.5772/46184

Kankaanpää P, Tuomola E, El-Nezami H, Ahokas J, Salminen SJ (2000) Binding of aflatoxin $\mathrm{B} 1$ alters the adhesion properties of Lactobacillus rhamnosus strain GG in a Caco-2 model. J Food Prot 63:412-414. https://doi.org/10. 1016/bs.aambs.2019.02.001

Knasmüller S, Mersch-Sundermann V, Kevekordes S, Darroudi F, Huber W, Hoe$|z| C$ et al (2004) Use of human-derived liver cell lines for the detection of environmental and dietary genotoxicants; current state of knowledge. Toxicology 198:315-328. https://doi.org/10.1016/j.tox.2004.02.008

Lahtinen S, Haskard C, Ouwehand A, Salminen S, Ahokas J (2004) Binding of aflatoxin B1 to cell wall components of Lactobacillus rhamnosus strain GG. Food Addit Contam 21:158-164. https://doi.org/10.1080/0265203031 0001639521

Lee HJ, Ryu D (2015) Advances in mycotoxin research: public health perspectives. J Food Sci 80:2970-2983. https://doi.org/10.1111/1750-3841.13156

Leiva A, Méndez G, Rodríguez C, Chinchilla FG (2019) Chemical assessment of mycotoxin contaminants and veterinary residues in Costa Rican animal feed. Int J Food Contam 6:5. https://doi.org/10.1186/s40550-019-0075-8

Lili Z, Junyan W, Hongfei Z, Baoging Z, Bolin Z (2018) Detoxification of cancerogenic compounds by lactic acid bacteria strains. Crit Rev Food Sci Nutr 58:2727-2742. https://doi.org/10.1080/10408398.2017.1339665

Luz C, Saladino F, Luciano F, Mañes J, Meca G (2017) In vitro antifungal activity of bioactive peptides produced by Lactobacillus plantarum against Aspergillus parasiticus and Penicillium expansum. LWT 81:128-135. https://doi.org/10.1016/j.lwt.2017.03.053

Magembe KS, Mwatawala MW, Mamiro DP, Chingonikaya EE (2017) Erratum to: assessment of awareness of mycotoxins infections in stored maize (Zea mays L.) and groundnut (Arachis hypogaea L.) in Kilosa District, Tanzania. Int J Food Contam 4:8. https://doi.org/10.1186/s40550-017-0054-x

Makau CM, Matofari JW, Muliro PS, Bebe BO (2016) Aflatoxin B1 and Deoxynivalenol contamination of dairy feeds and presence of Aflatoxin M1 contamination in milk from smallholder dairy systems in Nakuru, Kenya. Int J Food Contam 3:6. https://doi.org/10.1186/s40550-016-0033-7

Marín S, Cano-Sancho G, Sanchis V, Ramos AJ (2018) The role of mycotoxins in the human exposome: application of mycotoxin biomarkers in exposome-health studies. Food Chem Toxicol 121:504-518. https://doi. org/10.1016/j.fct.2018.09.039

Marrez DA, Shahy EM, El-Sayed HS, Sultan YY (2018) Detoxification of Aflatoxin B1 in milk using lactic acid bacteria. Res J Biol Sci 18:144-151. https://doi. org/10.3923/jbs.2018.144.151

Muhialdin BJ, Saari N, Meor Hussin AS (2020) Review on the biological detoxification of Mycotoxins using lactic acid Bacteria to enhance the sustainability of foods supply. Molecules 11:2655. https://doi.org/10.3390/molec ules 25112655

Nguegwouo E, Sone LE, Tchuenchieu A, Tene HM, Mounchigam E, Njayou NF, Nama GM (2018) Ochratoxin a in black pepper, white pepper and clove sold in Yaoundé (Cameroon) markets: contamination levels and consumers' practices increasing health risk. Int J Food Contam 5:1. https://doi. org/10.1186/s40550-017-0063-9

Ofori H, Tortoe C, Akonor PT, Ampah J (2016) Trace metal and aflatoxin concentrations in some processed cereal and root and tuber flour. Int J Food Contam 3:15. https://doi.org/10.1186/s40550-016-0038-2

Oliveira PM, Zannini E, Arendt EK (2014) Cereal fungal infection, mycotoxins, and lactic acid bacteria mediated bioprotection: from crop farming to cereal products. Food Microbiol 37:78-95. https://doi.org/10.1016/j.fm. 2013.06.003V

Oluwafemi F, Kumar M, Bandyopadhyay R, Ogunbanwo T, Ayanwande KB (2010) Bio-detoxification of aflatoxin B1 in artificially contaminated maize grains using lactic acid bacteria. Toxin Rev 29:115-122. https://doi.org/10. 3109/15569543.2010.512556

Patel KH, Kalaria RK, Kahimani MR, Shah GS, Dholakiya BZ (2021) Prevention and control of mycotoxins for food safety and security of human and animal feed. In: Fungi bio-prospects in sustainable agriculture, environment and Nano-technology, vol 3. Academic Press, pp 315-345. https:// doi.org/10.1016/B978-0-12-821734-4.00013-7

Pierides M, El-Nezami H, Peltonen K, Salminen S, Ahokas J (2000) Ability of dairy strains of lactic acid bacteria to bind aflatoxin M1 in a food model. $J$ Food Prot 63:645-650. https://doi.org/10.4315/0362-028X-63.5.645

Qian G, Tang L, Guo X, Wang F, Massey ME, Su J et al (2014) Aflatoxin B1 modulates the expression of phenotypic markers and cytokines by splenic lymphocytes of male F344 rats. J Appl Toxicol 34:241-249. https://doi. org/10.1002/jat.2866

RASFF annual report (2019), https://op.europa.eu/en/publication-detail/-/ publication/2c5c7729-0c31-11eb-bc07-01aa75ed71a1/language-en/ format-PDF/source-174742448. Accessed on April, (2021)

Rocha MEBD, Freire FDCO, Maia FEF, Guedes MIF, Rondina D (2014) Mycotoxins and their effects on human and animal health. Food Control 36:159-165. https://doi.org/10.1016/j.foodcont.2013.08.021

Salminen S, von Wright A, Morelli L, Marteau P, Brassart D, de Vos WM et al (1998) Demonstration of safety of probiotics - a review. Int J Food Microbiol 44:93-106. https://doi.org/10.1016/S0168-16059800128-7

Selmanoglu G, Koçkaya EA (2004) Investigation of the effects of patulin on thyroid and testis, and hormone levels in growing male rats. Food Chem Toxicol 42:721-727. https://doi.org/10.1016/j.fct.2003.12.007

Sengun I, Yaman D, Gonul S (2008) Mycotoxins and mould contamination in cheese: a review. World Mycotoxin J 13:291-298. https://doi.org/10.3920/ WMJ(2008.X041

Shehata MG, Badr AN, Sohaimy SAEl, Asker D, Awad TS (2019) Characterization of antifungal metabolites produced by novel lactic acid bacterium and their potential application as food biopreservatives. Ann Agric Sci 64:71-78. https://doi.org/10.1016/j.aoas.2019.05.002

Shephard GS (2008) Impact of mycotoxins on human health in developing countries. Food Addit Contam 25:146-151. https://doi.org/10.1080/02652 030701567442

Shetty PH, Jespersen L (2006) Saccharomyces cerevisiae and lactic acid bacteria as potential mycotoxin decontaminating agents. Trends Food Sci Technol 17:48-55. https://doi.org/10.1016/j.tifs.2005.10.004 
Shin HS, Lee HJ, Pyo MC, Ryu D, Lee KW (2019) Ochratoxin A-induced hepatotoxicity through phase I and phase II reactions regulated by AhR in liver cells. Toxins 11:377. https://doi.org/10.3390/toxins11070377

Smith GW (2018) Veterinary toxicology. Academic Press. https://doi.org/10 1016/B978-0-12-811410-0.00071-4

Speijers G, Franken M, Van Leeuwen F (1988) Subacute toxicity study of patulin in the rat: effects on the kidney and the gastro-intestinal tract. Food Chem Toxicol 26:23-30. https://doi.org/10.1016/0278-69158890037-3

Stiles ME (1996) Biopreservation by lactic acid bacteria. Antonie Van Leeuwenhoek 70:331-345. https://doi.org/10.1007/BF00395940

Topcu A, Tugba B, Refaat W, Ismail HB (2010) Detoxification of aflatoxin B1 and patulin by enterococcus faecium strains. Int J Food Microbiol 139:202205. https://doi.org/10.1016/j.jfoodmicro.2010.03.006

Wang X, Tang J, Geng F, Zhu L, Chu X, Zhang Y, Rahman SU, Chen X, Jiang Y, Zhu D, Zhu D, Feng S (2018) Effects of deoxynivalenol exposure on cerebral lipid peroxidation, neurotransmitter and calcium homeostasis of chicks in vivo. Toxicon 150:60-65. https://doi.org/10.1016/j.toxicon.2018. 05.010

Woloshuk CP, Shim WB (2013) Aflatoxins, fumonisins, and trichothecenes: a convergence of knowledge. FEMS Microbiol Rev 37:94-109. https://doi. org/10.1111/1574-6976.12009

Wu F, Groopman JD, Pestka JJ (2014) Public health impacts of foodborne mycotoxins. Annu Rev Food Sci Technol 5:351-372. https://doi.org/10. 1146/annurev-food-030713-092431

Zhai Y, Hu S, Zhong L, Lu Z, Bie X, Xhao H, Zhang C, Lu F (2019) Characterization of deoxynivalenol detoxification by Lactobacillus paracasei LHZ-1 isolated from yogurt. J. Food Prot 82:1292-1299. https://doi.org/10.4315/ 0362-028X.JFP-18-581

Zhang K, Wong JW, Krynitsky AJ, Trucksess MW (2016) Perspective on advancing FDA regulatory monitoring for mycotoxins in foods using liquid chromatography and mass spectrometry. J AOAC Int 99:890-894. https:// doi.org/10.5740/jaoacint.16-0116

\section{Publisher's Note}

Springer Nature remains neutral with regard to jurisdictional claims in published maps and institutional affiliations.

- fast, convenient online submission

- thorough peer review by experienced researchers in your field

- rapid publication on acceptance

- support for research data, including large and complex data types

- gold Open Access which fosters wider collaboration and increased citations

- maximum visibility for your research: over $100 \mathrm{M}$ website views per year

At BMC, research is always in progress.

Learn more biomedcentral.com/submissions 